\title{
A tribute to Margalith Galun (1927-2012)
}

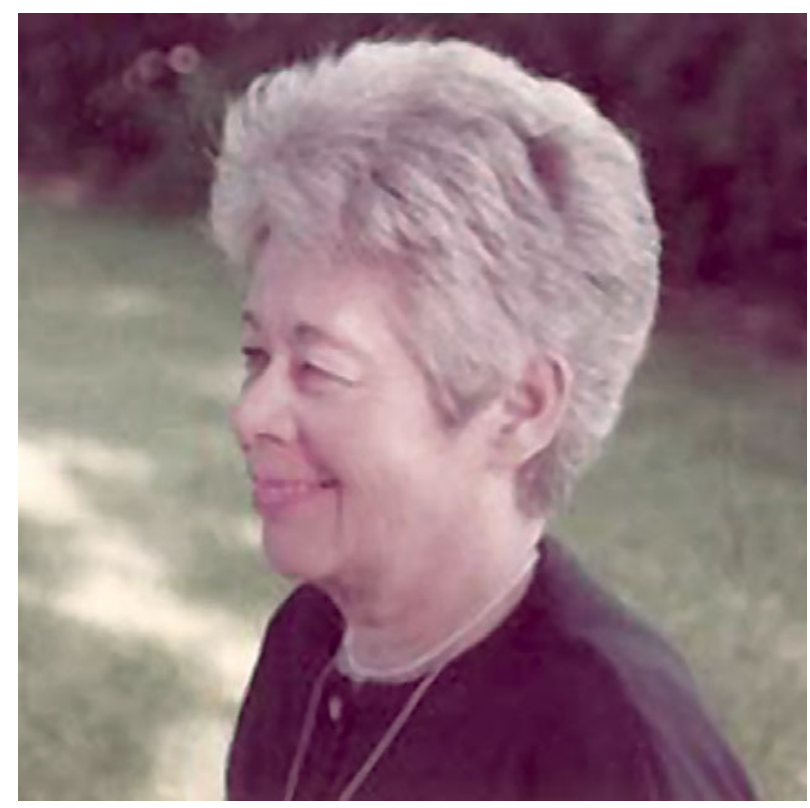

Margalith Galun was born in Austria but moved first to Switzerland and then, at the age of 20, to Israel where she studied at the Hebrew University of Jerusalem. She was awarded a Ph.D. in 1960, and in 1965 joined the Botany Department at Tel-Aviv University where she spent the remainder of her academic life (Balaban, 2012). Margalith became internationally recognized for her research on lichens. After her initial interest in the biodiversity of lichens in Israel, she focused her work on the early interaction between alga and fungus during thallus formation. She investigated this by electron microscopy and by undertaking research, with her students, on the signalling molecules involved. A side issue, the uptake of metals by lichens, involved collaboration with Jacob Garty, who became her colleague and extended this work. She presented the results of this research at major international conferences and via papers in journals over the years, in all, publishing over 90 contributions, her major ones appended to this obituary.

In 1985, Margalith founded and was first editor of Symbiosis, an international journal that she managed, remaining as Editor-inChief until 2006. In addition, she undertook the onerous task of editing the three-volume Handbook of Lichenology for CRC Press. We are personally aware of the hard work she put into this project, particularly when she found herself in the position of having to omit certain chapters or write them herself, as a number of would-be contributors failed to honour their promises - subsequently, she wrote twelve of the 54 chapters!

Margalith worked tirelessly for the International Association for Lichenology, being a firm believer in the importance of international co-operation; not only did she attend many of its meetings, but she was also an active member of its committee, serving as Vice-President from 1987 to 1993. She also 
organized the successful first International Symbiosis Congress in Jerusalem in November 1991 (Galun, 2011). This was attended by 250 people from 27 countries and three lichenologists, D.C. Smith, D.J. Hill and D.H.S. Richardson, contributed to the proceedings volume which ran to 500 pages (Symbiosis, 1992).

The imposition of political and financial constraints often put difficulties in Margalith's way, but she surmounted such problems, frequently at considerable self-sacrifice, with the result that Tel-Aviv University became an internationally acclaimed centre of excellence for the study of lichens. The outstanding success of her many research students testifies to her inspirational guidance. In addition to all her lichenological activities, Margalith was devoted to her family, besides shouldering a heavy burden of administrative duties arising from the senior academic position she held at Tel Aviv University (Balaban 2012).

We have been friends of Margalith for many years and spent many happy and profitable times together. We know that many other lichenologists have similar fond memories of her warm hospitality and unquenchable enthusiasm for lichenology. One of us (MRDS) made a prolonged visit to her in Israel in 1976, an experience he will never forget, while the other (DHSR) attended the First International Symbiosis Congress in 1991 in Tel-Aviv, and we both attended the 6th International Mycological Congress in 1998 in Jerusalem, of which Margalith was the key organizer. Unquestionably, she was one of the world's foremost lichenologists, and it was indeed fitting that she should be awarded the Acharius Medal by the International Association for Lichenology at the 5th International Mycological Congress, Vancouver in 1994. She is greatly missed by the lichen community worldwide.

\section{David H. S. Richardson and} Mark R. D. Seaward
Cited References

Balaban, M. (2012) Obituary: Professor Margalith Galun (1927-2012), founding Editor-in-Chief of Symbiosis. Symbiosis 56: 149-156.

Galun, M. (2011) The symbiosis community: how the journal, the conferences and the society began. Symbiosis 53: 47-48.

Symbiosis (1993) Selected papers from the International Symbiosis Congress, Jerusalem, November 17-22nd, 1991. Symbiosis 14: 1-500.

Selected Publications of Margalith Galun The following list includes some of the more notable of the $94+$ titles authored or co-authored by Margalith Galun; for a complete list of her publications see: Symbiosis 56: 153-156 (2012).

Galun, M. \& Reichert, I. (1965) Lichens of Mount Carmel. Israel fournal of Botany 14: 5-14.

Galun, M. \& Lavee, H. (1966) Lichens from Har Maron (Jebel Jermak), Upper Galilee. Bryologist 69: 324333.

Ben-Shaul, Y., Paran, N. \& Galun, M. (1969) The ultrastructure of the association between phycobiont and mycobiont in three ecotypes of the lichen Caloplaca aurantia var. aurantia. Fournal of Microscopy 8: 415-422.

Galun, M. (1970) The Lichens of Israel. Jerusalem: Israel Academy of Sciences \& Humanities.

Galun, M., Paran, N. \& Ben-Shaul, Y. (1970) The fungus-alga association in the Lecanoraceae: an ultrastructural study. New Phytologist 69: 599-603.

Galun, M., Paran, N. \& Ben-Shaul, Y. (1970) Structural modifications of the phycobiont in the lichen thallus. Protoplasma 69: 85-96.

Galun, M., Ben-Shaul, Y. \& Paran, N. (1971) The fungus-alga association in the Lecideaceae: an ultrastructural study. New Phytologist 70: 483-485.

Alon, G. \& Galun, M. (1971) The genus Caloplaca in Israel. Israel fournal of Botany 20: 273-292.

Galun, M., Marton, K. \& Behr, L. (1972) A method for the culture of lichen thalli under controlled conditions. Archiv fur Microbiologie 83: 189-192.

Galun, M., Kushnir, E., Behr, L. \& Ben-Shaul, Y. (1973) Ultrastructural investigation on the algafungus relation in pyrenocarpous lichen species. Protoplasma 78: 187-193.

Marton, K. \& Galun, M. (1976) In vitro dissociation and reassociation of the symbionts of the lichen Heppia echinulata. Protoplasma 87: 135-143.

Garty, J., Galun, M., Fuchs, C. \& Zisapel, N. (1977) Heavy metals in the lichen Caloplaca aurantia from urban, suburban and rural regions in Israel (a comparative study). Water, Air Soil Pollution 8: 171-188.

Kushnir, E. \& Galun, M. (1977) The fungus-alga association in endolithic lichens. Lichenologist 9: 123130. 
Kushnir, E., Tietz, A. \& Galun, M. (1978) “Oil hyphae" of endolithic lichens and their fatty acid composition. Protoplasma 97: 47-60.

Garty, J., Galun, M. \& Kessel, M. (1979) Localization of heavy metals and other elements accumulated in the lichen thallus. New Phytologist 82: 159-168.

Bubrick, P., Galun, M. \& Frensdorff, A. (1981) Proteins from the lichen Xanthoria parietina which bind to phycobiont cell walls. Localization in the intact thallus and cultured mycobiont. Protoplasma 105: 207-211.

Marton, K. \& Galun, M. (1981) The cyanophilous lichen population of the Arava Valley and the Judean Desert (Israel). Israel fournal of Botany 30: 125-155.

Galun, M. \& Bubrick, P. (1984) Physiological interactions between partners of the lichen symbiosis. In Encyclopedia of Plant Physiology (H.-F. Linskens \& J. Heslop-Harrison, eds): 362-401. Berlin: SpringerVerlag.

Galun, M., Bubrick, P. \& Frensdorff, A. (1984) Initial stages in fungus-alga interaction. Lichenologist 16: 103-110.

Bubrick, P. \& Galun, M. (1984) Cyanobiont diversity in the Lichinaceae and Heppiaceae. Lichenologist 16: 279-287.

Canaani, O., Ronen, R., Garty, J., Cahen, D., Malkin, S. \& Galun, M. (1984) Photoacoustic study of the green alga Trebouxia in the lichen Ramalina duriaei in vitro. Photosynthesis Research 5: 297-306.

Garty, J., Ronen, R. \& Galun, M. (1985) Correlation between chlorophyll degradation and the amount of some elements in the lichen Ramalina duriaei (De Not.) Jatta. Environmental and Experimental Botany 25: 67-74.
Garty, J., Galun, M. \& Hochberg, Y. (1986) The accumulations of metals in Caloplaca aurantia growing on concrete tiles. Lichenologist 18: 257-263.

Galun, M., ed. (1988) CRC Handbook of Lichenology. 3 vols. Boca Raton: CRC Press.

Galun, M. \& Garty, J. (1988) Soredia formation of compatible and incompatible lichen symbionts. In Cell to Cell Signals in Plant, Animal and Microbial Symbiosis: 207-217.

Kardish, N., Kessel, M. \& Galun, M. (1989) Characterization of symbiotic and cultured Nostoc of the lichen Nephroma laevigatum Ach. Symbiosis 7: 257266.

Kardish, N., Rotem-Abarbanell, D., Zilberstein, A. \& Galun, M. (1990) Comparison between the symbiotic Nostoc of the lichen Nephroma laevigatum Ach. and its cultured, isolated Nostoc by recombinant DNA. Symbiosis 8: 135-145.

Galun, M. \& Mukhtar, A. (1996) Checklist of the lichens of Israel. Bocconea 6: 149-171.

Silberstein, L., Siegel, B.Z., Siegel, S.M., Mukhtar, A. \& Galun, M. (1996) Comparative studies on Xanthoria parietina, a pollution-resistant lichen, and Ramalina duriaei, a sensitive species. II. Evaluation of possible air pollution-protection mechanisms. $\mathrm{Li}$ chenologist 28: 367-383.

Galun, M. \& Garty, J. (2001) Biologial soil crusts of the Middle East. In Biological Soil Crusts: Structure, Function, and Management (J. Belnap \& O. Lange, eds): 95-106. Berlin: Springer-Verlag. 